\title{
HIST1H3D Gene Mutation
}

National Cancer Institute

\section{Source}

National Cancer Institute. HIST1H3D Gene Mutation. NCI Thesaurus. Code C154317.

A change in the sequence of the HIST1H3D gene. 